\title{
Effects of Corporate Profitability and Growth on the Shareholding Strategies of Banks: Evidence from Japan
}

\author{
Kazuhiko Kobori ${ }^{1}$ \\ ${ }^{1}$ Department of Japanese, Wenzao Ursuline University of Languages, Kaohsiung, Taiwan (R.O.C) \\ Correspondence: Kazuhiko Kobori, Department of Japanese, Wenzao Ursuline University of Languages, No. 900, \\ Minzu 1st Road, Sanmin District, Kaohsiung City, 80793, Taiwan (R.O.C). Tel: 886-7-342-6031. E-mail: \\ 95061@mail.wzu.edu.tw
}

Received: July 8, 2020

Accepted: August 21, 2020

Online Published: August 25, 2020

doi:10.5539/ijef.v12n9p83

URL: https://doi.org/10.5539/ijef.v12n9p83

\begin{abstract}
This study scrutinised whether the profitability indexes of firms and the costs associated with product creation as reflections of growth potential affect the percentage of shareholding that Japanese banks acquire from Japanese client companies. To this end, multiple regression analysis was conducted on a sample of 302 firms on which 2,231 observations were made over the fiscal years 2006 to 2015. The findings indicated that the principle of shareholding alone does not drive banks to secure shares in client companies. Instead, the standard that prompts share acquisition is whether management is efficiently operating company business.

The implication of this study is that a bank's shareholding strategy requires client companies to implement management with an awareness of corporate governance, whose significance lies in advancing the realisation of returns from corporate activities by lenders and/or shareholders. In other words, banks are motivated to hold shares when client companies are highly profitable and efficient.

Even under these conditions, a bank carries on serving as the financial institution with which a client company is primarily affiliated. As a main bank, a given financial institution seems to consider the pursuit of long-term corporate profits through the research and development of a client firm. However, whether banks will continue to seek such profits from client companies is doubtful.
\end{abstract}

Keywords: bank, corporate governance, ROA, ROE, shareholding

\section{Introduction}

In the past, Japanese financial institutions were accorded protection by the Ministry of Finance in a practice called the convoy system (Note 1), wherein banks were shielded from competition. This system guaranteed effective credit creation (Note 2) and enabled banks to continue supplying funds to client firms, thus sustaining main bank relationships. These associations afforded many companies opportunities to innovate, offer inventive products to the market and attract consumers. However, such business culture eroded when other developed countries demanded deregulation and the opening of Japanese markets in the 1980s. For this reason, the Japanese government started moving towards financial liberalisation (Aoki \& Patrick, 1995). The subsequent collapse of the bubble economy in February 1991 further destabilised the financial system given the decline in stock and land prices under so-called asset deflation. Other outcomes from the abolition of convoy capitalism included the considerable reduction in investment and consumption, which caused a reverse asset effect; the yen's appreciation; and the suffering of the export industry (Maki, 2006).

The unstable financial conditions in Japan at the time can be attributed to various other reasons, amongst which one of the gravest was the decline in the practical management capabilities of banks. This decline compelled financial institutions to impose a credit crunch and deny the issuance of loan credit to client firms. These bank behaviours also evolved into social problems after the Heisei recession (Yoda \& Harootunian, 2006). Why did banks take such actions? The measures that they adopted were prompted by the bad debts that financial institutions could not recover because of bankruptcy amongst client companies. Banks had overfinanced firms during the bubble economy (Fukuda \& Koibuchi, 2006).

The accumulation of non-performing loans in 1998 motivated the lifting of restrictions on the establishment of financial holding companies - a development that led to major bank reorganisations. When a bad debt is charged 
off, a bank is required to record this as a loss on its income statement. A huge loss substantially diminishes a bank's capital, which is a problem amid the need to comply with international capital ratios that are regulated by the Bank for International Settlements. Banks that engage in domestic financial transactions are mandated to satisfy a volume of $4 \%$ in capital requirements, and banks that transact on an international scale are directed to meet an $8 \%$ quota. These capital requirements obligated Japanese banks to strengthen their capital standing, which they attempted to achieve by expanding capital through business integration. This consolidation, in practice, was tantamount to reorganisation (Itami, 2019) (Note 3).

The banking crisis ended after United Financial of Japan Bank was rescued through a merger with Tokyo Mitsubishi Bank in 2005 (Uebayashi, 2013), but by then, banks have become cautious about lending to companies. They thus imposed efficient operation as a prerequisite to loan approval. In other words, loan applications were evaluated on the basis of whether applicant companies can generate profits for banks-a behaviour triggered by changes in the environment surrounding these financial institutions. Recent years have seen other industries enter the domain of Internet banking, keeping pace with new technologies, such as fintech and virtual currency, which have altered the landscape of the banking business itself. In the Japanese setting, the population of Japan is declining whilst the market is shrinking (Note 4). This is why banks are concerned about the future of their original business models.

In August 2015, banks announced that on the basis of Japan's Corporate Governance Code (Note 5), in the event that a company where a bank is a shareholder fails to earn profits, the bank will release mutually held shares to the market. This orientation likewise changed company attitudes. They began distancing themselves from financial institutions as the latter ceased fund lending activities and demanded fund collection. As part of their strategies, some companies raised resources by issuing corporate bonds or increasing capital, in effect engaging in direct financing (Hoshi, Kashyap, \& Scharfstein, 1990). These schemes allowed companies to retain substantial profits - a phenomenon referred to as self-financing (Note 6) - as they dissolved their relationships with banks. Nevertheless, the particular complication arising from this situation is that operating in an era of uncertainty and deteriorating alliances with banks has caused companies to become reluctant to implement strategies for growth, such as research and development (R\&D) activities and capital investment initiatives. They tend to refrain from allocating retained earnings to innovation.

According to Schumpeter (1912), the work of banks is important for sustaining innovation, but if a bank is short on funds, then it cannot support the endeavours of companies to produce inventive products and services. The Japanese economy as a whole is caught in a vicious circle because of companies' management policy that discourages the pursuit of $R \& D$ activities for future growth and profitability.

When switching to shareholder-oriented management, important requirements are to clarify and quantify management goals (Shared, 1997). Management performance can also be measured using stock price, but this component is only an abstract index that represents management results (Note 7). On this basis, Shared (1997) argued that management indicators should be used to ascertain the management efficiency of companies. Amongst these indices, an effective efficiency measure as a proxy for shareholder profits is return on equity (ROE) or return on assets (ROA). Such index-oriented management is consistent with shareholder-leaning direction. The problem with Shared's (1997) work is that it did not look into these issues in an empirical fashion. Sheard's (1997) research did not provide evidentiary support regarding this matter. This study was therefore conducted as an endeavour to confirm the author's insights and perform the empirical investigation necessary for such validation.

Current companies, including banks, are required to implement corporate management in line with corporate governance codes, thereby compelling banks to release the stock of client firms that do not earn revenues. For their part, most companies that are forced to rely on indirect finance are also obligated to continue collaborating with banks. They are duty-bound to disclose profits on their income statements for them to be eligible for a continued alliance with financial institutions. In addition, companies are required to pay dividends for the purpose of implementing management that emphasises shareholder value. Because of these impositions, they are unable to afford $R \& D$ investment. The upshot of all these is pressure on companies to focus on finance rather than innovation.

In the past, main bank relationships in Japan stimulated financial institutions to encourage company innovation and manufacturing, which reflect growth potential (Aoki \& Patrick, 1995). This tendency stemmed from reinforcement by government policies and a rising economy. Under the current recession, however, no such support for innovation is deemed favourable. Compounding this problem is the advent of globalisation, which has driven banks to insist on acquiring short-term revenues from borrower companies. This backdrop gives rise 
to the question of whether banks prioritise corporate profitability or growth as a condition for acquiring shares in client firms. If a financial institution values its main bank relationship with a company, it will also be inclined to support the growth of its client firm. Conversely, if it attaches importance to corporate governance codes, it will be predisposed to pursue profit primarily.

On the basis of the issues discussed above, this study explored whether the profitability indexes of firms and the costs of product creation as reflections of growth potential affect the percentage of shares that banks acquire from client firms. The key findings showed that in securing company stock, banks are motivated not by the principle of shareholding but by whether company management is efficiently operating a business. An intriguing result is the positive influence of $R \& D$ expenditures, which reflect the long-term growth potential of companies, on bank shareholding in a client firm. Taken together, however, the results indicated that banks implement stockholding strategies that underscore company profitability instead of corporate growth.

In casting light on these matters, this research contributes to the existing literature as follows. It derived empirical evidence regarding the endurance of the main bank relationship system, which prior studies neglected to examine on the basis of financial indexes. The present work contends that this alliance between banks and firms has not expired, even in the current business climate. Additionally, this study accumulated novel results on main bank relationships.

\section{Literature Review}

\subsection{The Relationship between a Main Bank and a Firm}

Banks aim to maximise their gains as owners, and they have played a central role in monitoring the compliance of client companies with governance by securing firm shares (Aoki \& Patrick, 1995). This practice represents an attempt to solve the agency problem. Before the 1990s, share ownership by banks was no cause for financial institutions to prioritise profitability over a company's safety and growth strategies. They often extended lending services to companies, assuming the dual role of stockholder and creditor. This structure meant that when companies needed to innovate for growth, banks issued as many loans as possible for this purpose. Reciprocally, companies offered banks various benefits, including absorbing the surplus personnel of banks, safeguarding bank shares and directing company employees who need personal financing (i.e. new customers) to banks. These entities have thus built a win-win relationship with each other (Aoki \& Patrick, 1995) - a phenomenon that cannot be explained by agency theory. A more appropriate explanatory perspective is the concept of the main bank relationship. Under such association, indirect finance is a natural recourse for both bank and company, thereby perpetuating the immaturity of the stock market (Imai, 1989). However, the traditional Japanese management system completely changed after the collapse of the bubble economy, with companies gradually seeking direct financing and minimising dependence on banks (Iwata, 2011).

\subsection{Reconsidering Main Bank Relationships}

Japanese corporate society has witnessed the advancement of both globalism and corporate governance, but whether the main bank relationship system has actually weakened remains doubtful considering that such alliance has served as the foundation of the Japanese economic system (Woo \& Kanaya, 2000). The persistence of this relationship is exhibited by the fact that banks hold company shares, companies absorb excess human resources from banks and banks extend debt relief to client firms. Since the 2000s, opinions have continued to circulate that the main bank relationship system is a relic of the past, yet little research has been devoted to confirming such perspective and accordingly clarifying the future corporate environment in Japan. The literature review in the current work showed that main bank relationships have not necessarily ceased existing (Yoshimura, 2012). Uchida (2010) worte that the endurance of this system is evidenced by the minimal difference in bank shareholdings from $4.19 \%$ in 1987 to $4.18 \%$ in 1999 and the increase in issued loans from $5.43 \%$ in 1987 to 7.02\% in 1999 (Arikawa \& Miyajima, 2007). In addition, although shareholding by banks decreased from 14.9\% in 1987 to $7.7 \%$ in 2002, both main banks and firms continue to mutually hold stocks (Miyajima \& Kuroki, 2007). These findings are further supported by an analysis of main bank relationships for the period 1973 to 2008, which found that companies have not severed affiliations with their primary banks of choice (Hirota, 2009). Finally, although the percentage of loan issuance from main banks, indirect finance, decreased throughout the 1990s, companies continue to depend on these financial institutions (Arikawa \& Miyajima, 2007; Jackson \& Miyajima, 2007). Except for firms that directly finance their activities or have sufficient retained earnings, most enterprises do not have their own adequate sources of funding and have insufficient credibility to qualify for direct financing (Hirota, 2009). Therefore, these firms potentially view carrying on with main bank relationships as a safe strategy. It is important to note, however, that even though the main bank relationship system has not been completely terminated, strong partnerships between companies and banks have ended. For instance, banks 
and companies carried on with cross-holding, with the explicit aim of blocking potential hostile raids. The problem is that these institutions were also compelled to deal with bad debts. As a solution, the banks sold client companies' shares to offset losses and still earn profits after the collapse of the bubble economy. This situation pointed to the possibility that the main bank system would end, but in reality, financial institutions maintained their relationships with companies that needed indirect financing.

\subsection{The Effects of Corporate Governance on Bank Action}

Why have banks transformed into profit-oriented institutions in their dealings with client firms? The answer to this question is the permeation of corporate governance into Japanese society. In Japan's Corporate Governance Code, 'corporate governance' is defined as 'a structure for transparent, fair, timely and decisive decision-making by companies, with due attention to the needs and perspectives of shareholders and also customers, employees and local communities' (Tokyo Stock Exchange, Inc., 2018). This definition, however, was strongly disputed by Nakano (2017), who claimed that the corporate governance reform in the country caused a long-term economic stagnation that has persisted since 1990. The reform promoted monetisation as well as globalisation and led Japanese companies to favour short-term performance. It was also criticised as having made it difficult for innovation to occur in Japan.

Similar to other business entities, banks are companies that operate in collaboration with many stakeholders. As companies, they are required to comply with Japan's Corporate Governance Code, thus confronting them with challenges as regards maintaining shareholdings in unprofitable firms. If banks own stock in enterprises that fail to yield profits, then the shareholders of these financial institutions will evaluate bank CEOs as incompetent (Note 8).

At the same time, banks have carried on with their main bank relationships with companies because a decades-long association may be difficult for a bank to dissolve only because of compliance with corporate governance. The fact remains, however, that these institutions fear being threatened by shareholders who wish to adhere to relevant regulations. Convincing shareholders of the value offered by retaining main bank relationships necessitates projecting corporate management indicators as the best drivers of maintaining ownership in client firms.

\subsection{Management Considerations and Shareholding by Banks}

In Japan, ROE-oriented management is popular not only amongst individual investors but also with their institutional counterparts. Many listed companies regard augmenting ROE as an important management goal, and analysts believe that a high ROE (Note 9) translates to a great company. The preference for this index comes from the fact that the ROE of Japanese companies is excessively low compared with that of enterprises in other developed countries. Traditional Japanese companies usually involve themselves in indirect finance, under whose conditions banks take on the risks faced by client firms (Aoki \& Patrick, 1995). In other words, companies need not worry about financial risks as they are able to strive for their business goals with funding from banks.

The above-mentioned situation contrasts with the current business landscape, wherein fund acquisition in large listed firms is dominated by direct financing and self-financing rather than indirect financing. The disadvantage of direct financing is that corporate managers are pressured by shareholders to generate revenues and pay dividends. Companies are also obligated to keep in constant abreast of rising stock prices. Put differently, it is no longer possible to disregard ROE as an indicator of growth from the perspective of shareholders (Ahsan, 2012).

Notwithstanding the importance of ROE, however, focusing solely on this index in measuring company profitability is dangerous for managers and shareholders because if interest-bearing debt increases, the risk of bankruptcy also rises during a recession. Shareholders should carefully approach substantial investments that are anchored in corporate interest-bearing debt. Such caution is dictated by the insufficiency of reflecting revenues on income statements as a guarantee of profitability. A necessary task is for companies to continue generating cash flow that allows interest payments and debt repayments.

Shared (1997) averred that Japanese companies are characterised by less efficient management than are US enterprises given that the former expand their capital without remitting retained earnings to shareholders. As a result, the ROEs of Japanese companies have fallen. The author also expressed opposition to Japanese companies' acquisition of their own shares to raise the ROEs of their firms (Shared, 1997). A more suitable strategy for increasing ROE is for an enterprise to introduce a holding company (Note 10) and adhere to the Japan's Corporate Governance Code. A mere improvement in ROE figures does not necessarily mean financial solvency. 
Alternatively, ROA is an index favoured from the standpoint of management. Whereas ROE's denominator is shareholder equity, that of ROA is total assets, but both numerators constitute net income. ROE is a direct measure of whether equity is being managed efficiently and therefore represents the interests of shareholders. By contrast, ROA is an index of how much profit is generated through total assets invested using externally procured funds, such as shareholder equity and bank loans. This index shows whether the funds of all shareholders, including cross-shareholding financial institutions, are being managed efficiently. That is, ROA is a more effective indicator than ROE for banks.

\subsection{The Conditions Surrounding $R \& D$ Expenditure}

Innovation arises from community organisations and long-lasting relationships (Nakano, 2017). To put it another way, innovation is engendered by lifetime employment, seniority and the main bank relationship system, which embody conventional Japanese management. In the manufacturing industry, for example, valuable and competitive products influence a company's performance. Such commodities are developed through R\&D activities, which are therefore critical initiatives for companies. The problem, as previously explained, is that Japanese business today obligates companies to consider shareholder interests, thereby motivating a preference for business alliances that are cost-effective in the short term over those that are profitable in the long run. Under this orientation, investing in $R \& D$ is viewed as risky owing to the unpredictability of how $R \& D$ investments will turn out. Current Japanese companies believe that a more efficient strategy is to acquire a company engaged in the business that they need and offers retained earnings than to pursue R\&D activities (Note 11).

The trends that characterise R\&D expenditure are optimal bases for monitoring long-term competitiveness (Arikawa, Kawanishi, \& Miyajima, 2011). The R\&D expenses of large Japanese companies have consistently increased over the long term. Data from the Japanese Ministry of Economy indicated that R\&D costs increased between 1980 and 2007 and that spending infused into R\&D initiatives has exceeded the amount of capital investment since the early 2000s.

In Japan, changes in total $R \& D$ expenditures are monitored and reported by the Ministry of Public Management. In 2007, such total R\&D reached nearly 19 trillion yen (about US $\$ 190$ billion), but it decreased to 17 trillion yen (approximately US $\$ 170$ billion) in 2009. Since then, these figures have plateaued before exhibiting an upward trend. In 2014, total R\&D spending recovered to the levels observed in 2007, but it has been diminishing slightly since the end of 2015. Furthermore, the ratio of R\&D expenditures to the GDP has remained in the upper 3\%, albeit a moderate decrease has been observed after this development. As can be seen, costs associated with R\&D in Japan have been stable even as mergers and acquisitions (M\&A) actively occur. Amplifying R\&D spending in the future necessitates boosting the economy, increasing the population, extending international trade and expanding domestic demand. It takes five to ten years for R\&D investment to be profitable. For this reason, companies that place emphasis on such investment implement management on the grounds of long-term competitiveness. This was the strength of Japanese manufacturing - an enduring competitiveness that has secured employment and supported the lives of many people (Koike, 2015).

As with the challenge that Japanese companies face with respect to innovation, R\&D targets present difficulties in equal measure given a climate that advocates short-term profits through corporate governance reforms. As discussed earlier, these circumstances encourage a preference for shareholding in profitable companies over R\&D-intensive enterprises. The same holds true for banks given their position as corporate shareholders; that is, the company stock that they own are also held by third parties and/or related entities. Banks are therefore precluded from disregarding the interests of their own shareholders and adherence to corporate governance codes. In line with this situation, the following hypothesis was constructed:

Japanese banks focus on the profitability, rather than the growth, of a company as a standard for acquiring company shares under regulation by Japan's Corporate Governance Code.

\section{Methodology}

\subsection{Sample Selection}

The following samples are selected based on the above-mentioned temporary structure. The sample consisted of firms listed in the Japanese stock exchange from 2006 to 2015. The selection criteria are as follows:

1) Japanese firms that are appointed (Note 12) on the fiscal year that starts on April 1 and ends on March 31.

2) Firms that do not belong to the securities, insurance or utility industry.

The financial data of the sample were obtained from EOL (a database developed by Pronexus Inc. (Note 13), 2019), and data on bank ownership of company shares were derived from Kabunushi Pro (Note 14). Accounting 
data were taken from the consolidated financial statements of the investigated firms for the period examined in this work.

The initial dataset contained 23,365 observations, out of which 21,122 did not reflect a disclosure of R\&D expenditures (Note 15). Given that 12 of the companies had missing data, they were excluded from the study, leaving a final sample of 302 firms on which 2,231 observations were made over the fiscal years 2006 to 2015 .

\subsection{Research Method}

This study explored whether the profitability indexes of firms and the costs of product creation as reflections of growth potential affect the percentage of shares that banks acquire from client firms. And then, this study established the hypothesis, Japanese banks focus on the profitability, rather than the growth, of a company as a standard for acquiring company shares under regulation by Japan's Corporate Governance Code. On the basis of the established hypothesis, Eq. (1) was used as an analytical model intended to ascertain whether the profitability of firms and the amount of $R \& D$ spending influence the percentage of company stock acquired by banks. In the model, the dependent variable is the percentage of company shares held by a bank and the independent variables are profitability, ROA and ROE. The model also includes control variables and R\&D expenditures as a variable for manufacturing. Model 1 is written as follows:

$$
B A N K_{-} O W N E R=\alpha+\beta_{1} R O A_{i t}+\beta_{2} R O E_{i t}+\beta_{3} R \& D_{i t}+C V+e
$$

where BANK_OWNER represents the shareholding percentage owned by a bank, ROA denotes the ratio of net income to total assets of a company, $R O E$ is the company's return on equity and $R \& D$ indicates the amount of $R \& D$ expenditures of the firm. The unit amount is 1 million yen.

Two control variables were incorporated into the model. The first is the size of an accounting firm (BIG_AUDIT), which is a dummy variable. A huge accounting firm is assigned a value of 1 ; otherwise, the company is designated a value of 0 . The second control variable is the profit attributable to a parent owner (INCOME), which is expressed in units of 1 million yen. The descriptive statistics and correlations are shown in Table 1.

Table 1. Descriptive Statistics $(N=2,231)$

\begin{tabular}{lccccc}
\hline Variables & Mean & Median & Max & Minimum & Standard Deviation \\
\hline BANK_OWNER & 20.621 & 18.300 & 61.000 & 0.000 & 12.756 \\
ROA & 1.917 & 2.620 & 23.080 & -204.950 & 8.348 \\
$R O E$ & 5.614 & 4.850 & 3825.940 & -788.460 & 99.688 \\
$R \& D$ & 10340.600 & 815.000 & 634130.000 & 0.000 & 43282.570 \\
BIG_AUDIT & 0.819 & 1.000 & 1.000 & 0.000 & 0.385 \\
INCOME & 8819.570 & 1087.000 & 600039.000 & -215499.000 & 37023.270 \\
\hline
\end{tabular}

The average percentage of stock that a company issues to a bank is within the 5\% allowable by antitrust law. Antitrust legislation prohibits financial institutions (banks or insurance companies) from holding more than 5\% (in principle) of the voting rights of the general shareholders of domestic general companies. This regulation, however, can be circumvented. That is, multiple banks are allowed to pool their shares and a single bank is permitted by Japan's Financial Services Agency to hold more than 5\% of company shares provided that an enterprise requires special support from a bank. In this analysis, the mean value of BANK_OWNER is 20.621. Most banks hold client company shares jointly with other banks, in which case the maximum amount of BANK_OWNER is 61.000. A number of companies may be extended a bailout by a bank.

The mean $R O A$ obtained in this work is 1.917 . The average ROAs of Japanese companies belonging to all industries in 2012 and 2016 were 1.5\% and the lower end of 2\%, respectively (Takata, 2017). Therefore, the $R O A$ in this research is reasonable. On the other hand, the mean $R O E$ is 4.85 . The average ROEs in the aforementioned periods were around $4 \%$ and the lower end of $6 \%$ range, respectively (Takata, 2017), also indicating the acceptability of the data derived in this study. The mean value of BIG_AUDIT is 0.819, signifying that large accounting firms dominate the provision of audit services to listed firms in Japan (Note 16).

The mean ROA is 1.917 and the mean ROE is 5.614. Here, the ROA is calculated as the ratio of net income in a given period to the total value of a company's assets. The ROE, which is treated as a measure of financial performance, is computed by dividing net income by shareholder equity.

At first, the following is the ROA equation: 
ROA $=$ Net income $/$ Total Assets,

Next, the following is the ROE equation:

ROE = Net Income / Shareholder's equity,

From the above equation, the following formula is derived:

ROE $=$ ROA $\{$ Profitability $($ Net income $/$ Sales $) \times$ Asset turnover $($ Sales $/$ Total Assets $)\} \times$ Leverage (Total Assets $\times$ Shareholder's equity)

That is, the ROE equation involves multiplying ROA by leverage. The mean value is substituted into the ROE equation, yielding

$$
\mathrm{ROE}=\mathrm{ROA} \times \text { Leverage }, \quad 5.917=1.917 \times \text { Leverage, Leverage }=2.928
$$

According to the data of the Ministry of Finance [this data excluded those on financial institutions listed in the Tokyo stock price index (Topix 500)], the leverage of Japanese companies was $2.5 \%$ from 2012 to 2016 . The value derived on the basis of the study sample is slightly higher $(0.428)$. This difference can be attributed to the possibility that the sample companies implement financial strategies that are grounded in considerable leverage, as opposed to the practice of Topix 500 enterprises. The latter consist of companies with high market capitalisation and may use capital rather than debt for operations.

Table 2. Correlation coefficients $(N=2,231)$

\begin{tabular}{|c|c|c|c|c|c|c|}
\hline & BANK_OWNER & $R O A$ & $R O E$ & $R \& D$ & BIG_AUDIT & INCOME \\
\hline BANK_OWNER & 1.000 & & & & & \\
\hline$R O A$ & $0.175 * * *$ & 1.000 & & & & \\
\hline$R O E$ & -0.012 & $-0.105 * * *$ & 1.000 & & & \\
\hline$R \& D$ & $0.272 * * *$ & 0.032 & 0.001 & 1.000 & & \\
\hline BIG_AUDIT & $0.112 * * *$ & $0.125 * * *$ & $-0.037 *$ & $0.090 * * *$ & 1.000 & \\
\hline INCOME & $0.253 * * *$ & 0.156 *** & 0.023 & $0.751 * * *$ & $0.062 * *$ & 1.000 \\
\hline
\end{tabular}

Table 2 presents the Pearson correlations amongst BANK_OWNER, ROA, ROE, R\&D and the control variables. All the variables, except $R O E$, are highly correlated with stock ownership by banks in client companies.

\section{Results}

Table 3 displays the results of model 1. The analysis was conducted under the assumption that profitability indexes, such as $R O A$ and $R O E$, affect the shares that banks acquire from client firms but that R\&D spending exerts no such influence.

Table 3. Results of multiple regression

\begin{tabular}{|c|c|c|c|c|c|}
\hline Variables & & Coefficient & $t$-value & $p$-value & \\
\hline Intercept & & 17.483 & 29.010 & 0.000 & $* * *$ \\
\hline$R O A$ & & 0.227 & 7.180 & 0.000 & $* * *$ \\
\hline$R O E$ & & 0.001 & 0.230 & 0.822 & \\
\hline$R \& D$ & & 0.000 & 6.850 & 0.000 & $* * *$ \\
\hline$B I G \_A U D I T$ & & 2.290 & 3.410 & 0.001 & $* *$ \\
\hline INCOME & & 0.000 & 2.160 & 0.031 & $* *$ \\
\hline Adjusted $R$-square & 0.106 & & & & \\
\hline$N$ & 2,231 & & & & \\
\hline
\end{tabular}

Note. $*, * *$ and $* * *$ denote two-tailed significance at the $0.1,0.05$ and 0.001 levels, respectively.

The $F$-test showed that the statistical goodness-of-fit of the empirical model is significant at 0.001 . The adjusted $R^{2}$ value of the model is 0.106 , suggesting that the model serves as a good predictor of the dependent variable on the basis of the independent variables.

With reference to the relationship between each independent variable and the dependent variable, $R O A$, as expected, has a positive influence on the percentage of shares held by banks (coefficient $=0.227, p=0.000$ ). 
Contrary to expectations, $R O E$ is unrelated to the aforementioned percentage. The results on $R \& D$, which is an indicator of manufacturing costs, also contradicted what was anticipated in this work. Specifically, it is positively associated with a bank's shareholding percentage (coefficient $=0.000, p=0.000$ ). However, its coefficient is infinitely close to 0 .

With regard to BIG_AUDIT, the relationship between the employment of a huge accounting firm and a bank's shareholding percentage is very strong (coefficient $=2.290, p=0.001$ ). Finally, INCOME significantly influences the proportion of company shares acquired by a bank (coefficient $=0.000, p=0.031$ ).

\section{Additional Test}

An additional test was performed, with the control variables modified to confirm the robustness of model 1 . Specifically, BIG_AUDIT was incorporated as an external variable, and all the control variables were changed to internal ones. This approach was prompted by the need to determine whether similar results can be obtained even if external factors are eliminated. The results of the test indicate no serious variable-related problems in this work and therefore suggest the stable explanatory power of the main findings.

This section details the robustness test conducted to verify that the findings of the analysis are not mere coincidence. For this test, the control variables used were price earnings ratio $(P E R)$, profit-to-capital ratio $(C A P I T A L)$ and operating profit margin (SALES). The control variables in model 1 were changed for the following reasons: First, $P E R$ was adopted because an investor determines the investment value of a company on the basis of this indicator. Second, CAPITAL was selected as another control variable given this study's use of ordinary income instead of net income in the ROA formula. Net income can be manipulated at the discretion of management, but this procedure is not as easily accomplished when it comes to ordinary income. CAPITAL was hence deemed more representative of the efficiency of a company's normal business dealings. Its use was also regarded as reinforcive of the main results. Finally, SALES was employed because it is an index that shows whether companies are efficiently operating their main business. The results of the robustness test are presented in Table 4.

Table 4. Results of robustness test

\begin{tabular}{lcccc}
\hline Variables & Coefficient & $t$-value & $p$-value & \\
\hline Intercept & 18.535 & 52.940 & 0.000 & $* * *$ \\
$R O A$ & 0.000 & 13.200 & 0.000 & $* * *$ \\
$R O E$ & 0.001 & 0.270 & 0.786 & \\
$R \& D$ & 0.082 & 1.700 & 0.090 & $*$ \\
PER & 0.007 & 1.130 & 0.258 & \\
CAPITAL & 0.199 & 3.720 & 0.000 & $* * *$ \\
SALES & 0.012 & 1.120 & 0.263 & \\
Adjusted $R$-square & & & & \\
$N$ & 0.108 & & &
\end{tabular}

As can be seen from the findings, $R O A$ and $R \& D$ are positively related (coefficient $=0.000$ and $0.082, p=0.000$ and 0.090 , respectively) to a bank's shareholding percentage, whereas $R O E$ is unrelated to the dependent variable. As described above, the findings on $R O A, R O E$ and $R \& D$ are nearly consistent with the main results. The statistical significance of CAPITAL reinforces the core findings on ROA. This congruence is ascribed to the use of ordinary income instead of net income as the numerator in the computation of the profit-to-capital ratio. The value of the numerator is higher for ordinary income than for net income. Thus, the coefficient of CAPITAL is higher than that of ROA. Considering these outcomes, management efficiency influences the percentage of shares acquired by banks. They also corroborate the reasonableness of the overall findings.

\section{Discussion and Conclusion}

This study has examined whether the profitability indexes of firms and the costs of production as signs of growth potential bear on the percentage of client firm stock held by a bank. And then, this study established the hypothesis, Japanese banks focus on the profitability, rather than the growth, of a company as a standard for acquiring company shares under regulation by Japan's Corporate Governance Code. The findings confirmed the positive relationship of $R O A$ with the aforementioned percentage and the absence of such association with respect to ROE. Additionally, although R\&D spending is positively related to a bank's shareholding percentage, 
its coefficient is infinitely close to 0 . These outcomes imply that banks are moderately interested in manufacturing and company growth as drivers of shareholding.

ROA, which indicates how profitable a company is relative to its total assets, was found to pose an effect on the volume of shares acquired by a bank. It is calculated using externally procured funds, such as shareholder equity and bank loans in total assets. Shareholder equity may also include funds invested by banks. When ROA is used as a standard, there is a high possibility that the capital invested by a bank and/or the loan that it provides is managed efficiently. Under this scenario, then, financial institutions will be motivated to continue holding on to client company shares.

Conversely, ROE exerts no effect on the shareholdings of banks. As Shared (1997) explained, banks may be inclined to cautiously approach ROE-oriented management given that interest-bearing debt increases if a company uses leverage for operations. In this situation, it is equally essential for a firm to have enough cash to pay interest and repay debt. Furthermore, a company can increase its ROE by purchasing its own shares. Note, nonetheless, that although a company's ROE is high, there is a risk that it will avail itself of debt financing. Therefore, this index would not affect the percentage of shares held by a financial institution. Banks decide on holding client shares from a management perspective (i.e. ROA orientation) rather than from a shareholder standpoint (i.e. ROE preference). These results are compatible with those of Shared (1997). Correspondingly, ROA is more important than ROE as a benchmark for efficient management. Moreover, banks do not regard companies that devote resources to R\&D as characterised by inefficient management. This research assumed that a bank holds shares in a client company shares in consideration of its growth potential.

This research has provided meaningful results for investors and researchers interested in the Japanese economic system. A specific point that may elicit attention is the consideration of banks for the management efficiency of client companies as grounds for decision making on shareholding, in accordance with the stipulation of Japan's governance code. In other words, banks implement management in conformity with the code as a possible coping strategy for globalisation around the world.

Next, opinions abound as to the importance of ROE over ROA as a measure of company profitability and efficiency in Japan. However, this study demonstrated that banks place more emphasis on ROA than ROE. This propensity stems from the fact the calculation of ROE encompasses leverage. In general, most Japanese companies might be averse to debt financing in managing their businesses. This accords with the likelihood that banks focus on indicators that signal efficient operation than those that indicate debt utilisation.

The limitations of the research are worth noting. The sample period spanned only 10 years. The data cover only the period at which the main bank relationship weakened owing to globalisation. Until the 1980s, bank failures were extremely rare, and the main bank relationship system was flourishing. The stability of the financial system was maintained, thus enabling the reflection of actual economic trends. At that time, as well, financial authorities actively intervened in case of deterioration in bank management. Comparing that period with the era spanning 1991 to the present time after the bubble burst may reveal behaviours relevant to a bank's shareholding strategies.

Many Japanese firms do not disclose R\&D expenditures on their income statements, which is why the number of companies included in the sample decreased. Moreover, $R \& D$ expenditures and net income were directly used in the analysis. The results may have been different had these elements been divided by sales amounts and then used as variables. Division on the basis of sales can, as much as possible, eliminate the influence of size and company size. These percentages can then be used as indicators of management efficiency, profitability and growth potential, other than ROA and ROE, regardless of the size of an enterprise. The findings derived will be more generalisable to other contexts.

As part of future plans for this stream of research, I intend to add capital expenditure as a variable in the model as this can represent spending devoted to manufacturing. Because capital investment covers both expansion costs and $R \& D$ expenditures, including capital expenditure in the model will enable me to examine whether banks increase or decrease the shares that they hold in client companies. Capital investment directly affects a company's production activities. This investment is a corporate action that exerts a significant impact on company performance in the medium to long terms. It is necessary to delineate how the capital investment variable is added to a model as a source of influence on a bank's holding strategy. Including it is expected to clear the way for observing the characteristics of bank investment and shareholding behaviours. In the final analysis, this will help confirm the relationship between a bank's stockholding strategies and corporate growth under globalisation. Finally, banks acquire stock from companies with good management efficiency and such enterprises may retain substantial earnings. Consequently, banks might aim to acquire these companies through 
shareholdings for access to retained earnings. Clarifying these matters can validate whether the main bank relationship system of Japan has in truth ended.

\section{References}

Ahsan, A. M. (2012). Can ROE be used to predict portfolio performance? Economics, Management, and Financial Markets, 7(2), 132-148.

Aoki, M., \& Patrick, H. (1995). The Japanese main bank system: Its relevance for developing and transforming economies. Oxford University Press, Oxford. https://doi.org/10.1093/0198288999.001.0001

Arikawa, Y., \& Miyajima, H. (2007). Relationship banking in post-bubble in Japan: Coexistence of soft- and hard budget constraints. In M. Aoki, G. Jackson, \& H. Miyajima (Eds.), Corporate Governance in Japan. Oxford University Press, Oxford. https://doi.org/10.1093/acprof:oso/9780199284511.003.0002

Arikawa, Y., Kawanishi, T., \& Miyajima, H. (2011). Debt, ownership structure, and R\&D investment: Evidence from Japan. In RIETI Discussion Paper Series, 11-E-013.

Fukuda, S. I., \& Koibuchi, S. (2006). The impacts of "shock therapy" under a banking crisis: Experiences from three large bank failures in Japan. The Japanese Economic Review, 57(2), 232-256. https://doi.org/10.1111/j.1468-5876.2006.00375.x

Hirota, S. (2009). Main bank relationships in Japan: From monitoring to risk hedging. In RIETI Discussion Paper Series, 09-J-023.

Hoshi, T., Kashyap, A., \& Scharfstein, D. (1990). Bank monitoring and investment: Evidence from the changing structure of Japanese corporate banking relationships. In Asymmetric information, corporate finance, and investment, 105-126. University of Chicago Press, Chicago. https://doi.org/10.3386/w3079

Imai, K. I. (1989). Evolution of Japan's corporate and industrial networks. In Industrial dynamics (pp. 123-155). Springer, Dordrecht. https://doi.org/10.1007/978-94-009-1075-1_6

Itami, H. (2019). Management in Heisei. Nikkei Business Publications, Inc,. Tokyo.

Iwata, K. (2011). Japan's bubble, deflation, and long-term stagnation. MIT Press, Massachusetts.

Jackson, G., \& Miyajima, H. (2007). Varieties of capitalism, varieties of markets: Mergers and acquisitions in Japan, Germany, France, the UK and USA. RIETI Discussion Paper Series, 07-E-054. https://doi.org/10.2139/ssrn.1012210

Kawasaki, Y., \& Takashima, M. (2014). International strategy of SMFG, Retrieved on September 21, 2019 from https://www.smfg.co.jp/investor/financial/small/pdf/20141017_pre.pdf

Koike, K. (2015). Long term competiveness: The crucial foundation of employment. Nikkei Business Publications, Inc,. Tokyo.

Lafley, A. G., \& Tichy, N. M. (2011). The art and science of finding the right CEO. Harvard Business Review, 89(10), 66-74.

Maki, A. (2006). Changes in Japanese household consumption and saving behavior before, during and after the Bubble era: empirical analysis using NSFIE micro-data sets. Japan and the World Economy, 18(1), 2-21. https://doi.org/10.1016/j.japwor.2004.04.004

MARROnline Sites. (2019). M \& A trends as seen in the graph. Retrieved on September 21, 2019 from https://www.marr.jp/genre/graphdemiru

Miyajima, H., \& Kuroki, F. (2007). The unwinding of cross-shareholding in Japan. Oxford University Press, Oxford.

Morita, Y. (2011). Analysis of the audit market. Kigyou Kaikei, 63(5), 81-86.

Nakano, T. (2017). True story: Business Theory. Kodansha Ltd, Tokyo.

Schoppa, L. (2006). Race to the bottom? Japanese multinational firms and the future of the lifetime employment system. The Asia-Pacific Journal, Japan Focus Volume, 4(3).

Schumpeter, J. A. (1912). Theorie der wirtschaftlichen Entwicklung. Munich and Leipzig: Duncker \& Humblot (in fact already published in 1911; 2nd Edition, 1926).

Sheard, P. (1997). The crisis of main bank capitalism: How Japanese-style management will change with "Big bang". Toyo Keizai Inc., Tokyo. 
Takata, H. (2017). Japanese companies' earning power has increased. However, Japanese companies are less profitable than the US. One Mizuho, 13(11), 1-2. in Japanese., Retrieved on September 21, 2019 from https://www.mizuho-ri.co.jp/publication/research/pdf/today/rt171113.pdf

Tokyo Stock Exchange, Inc. (2018). Japan's corporate governance code, Seeking sustainable corporate growth and increased corporate value over the mid-to long-term. Tokyo Stock Exchange, Inc., Tokyo. Retrieved on September 21, 2019, from https://www.jpx.co.jp/english/news/1020/b5b4pj000000jvxr-att/20180602_en.pdf

Uchida, H. (2010). Economic analysis of financial functions and banking. Nikkei Business Publications, Inc,. Tokyo.

Uebayashi, N. (2013). Changing Japanese style of management. Chuoukeizai-sha, Tokyo.

Woo, M. D., \& Kanaya, M. A. (2000). The Japanese banking crisis of the 1990's: Sources and lessons (No. 0-7). International Monetary Fund. https://doi.org/10.5089/9781451842401.001

Yoda, T., \& Harootunian, H. (Eds.). (2006). Japan after Japan: Social and cultural life from the recessionary 1990s to the present. Duke University Press, Durham. https://doi.org/10.1215/9780822388609

Yoshimura, N. (2012). Who controls the company? Corporate governance in Japan. Kodansha Ltd., Tokyo.

\section{Notes}

Note 1. The Japanese government acts as an escort, guiding and protecting Japanese firms along their achievement of economic progress (Schoppa, 2006).

Note 2. Credit creation is a system that creates deposit currency that is many times the original amount through lending operations between banks.

Note 3. The Financial Reconstruction Law was enforced in 1998, with the objectives of resolving bank failure and protecting depositors during economic crises. Small and medium-sized banks had to look for a bridge bank within 3 years or settle should they be unable to do so. Contrastingly, megabanks were temporarily nationalized so as to prevent their bankruptcy. After this, these larger banks were then compelled to also find a bridge bank.

In addition, in keeping with the Act on Emergency Measures for Early Strengthening of Financial Functions, the government injected public funds into banks to prevent their bankruptcy.

Note 4. Megabanks are looking for new business opportunities through partnerships and acquisitions with banks in Southeast Asia (Kawasaki \& Takashima, 2014).

Note 5. Principle 1-6 consists of a provision for 'Capital Policy that May Harm Shareholder Interest'. The principle is as follows: 'With respect to a company's capital policy that results in the change of control or in significant dilution, including share offerings and management buyouts, the board and kansayaku ('supervisor') should, in order not to unfairly harm the existing shareholders' interests, carefully examine the necessity and rationale from the perspective of their fiduciary responsibility to shareholders, should ensure appropriate procedures, and provide sufficient explanation to shareholders' (Tokyo Stock Exchange, Inc., 2018).

Note 6. Self-financing consists of retained earnings and depreciation.

Note 7. Uebayashi (2013) reported that profits and sales have been emphasized as traditional indicators of business performance. Stock price had not been so important in Japan.

Note. 8. The term of a CEO in the USA has been shortened. In a Fortune 500 company, the tenure of a CEO was reduced from nine and a half years to three and a half years (Lafley \& Tichy, 2011). As declared by Yoshimura (2012), corporate governance is one method of easily replacing managers with poor corporate performance in Japan.

Note 9. In general, ROE is an index used when making investment decisions from the perspective of shareholders. This is an indicator of how much net income is generated against shareholder equity (capital paid by shareholders and retained earnings). The higher the ROE, the more profits are obtained with less funding. That is, a company with a high ROE is one with a high investment value.

Note 10. This is because the establishment of a holding company enables efficient group management. For example, a holding company can formulate a management strategy whilst an operating company concentrates on its own business. Amid this setting, efficient business management becomes possible, and ROE increases.

Note 11. The ratio of M\&A between Japanese companies has been rising since 2011. About 1.100 cases were 
completed in 2011, and about 2.800 cases were concluded in 2018 (MARR Online, 2019).

Note 12. For many companies in Japan, March is the end of the fiscal year.

Note 13. The Pronexus Inc., as a specialist firm providing information processing services relating to corporate disclosure and investor relations activities, comprehensively supports the pertinent disclosure of information from its clients to investors.

Note 14. Yuho data mining Incs., operates a site called "Kabunushi Pro". The securities report of Japanese listed companies are disclosed to the public for free.

Note 15. Disclosures regarding R\&D spending vary depending on company. A firm regards the costs of R\&D activities as R\&D expenditures. A company can also record expenses incurred from $R \& D$ initiatives on an income statement as broken down into material, personnel and depreciation costs. These companies aggregate the aforementioned costs separately and disclose them as R\&D expenditures as a footnote to an income statement.

Note 16. Morita (2011) found that over $80 \%$ of the companies listed in the first section of the Tokyo Stock Exchange are audited by huge accounting firms.

\section{Copyrights}

Copyright for this article is retained by the author(s), with first publication rights granted to the journal.

This is an open-access article distributed under the terms and conditions of the Creative Commons Attribution license (http://creativecommons.org/licenses/by/4.0/). 